\title{
NITRATE AND POTASSIUM DYNAMICS IN PROFILES OF SOILS CULTIVATED WITH FERTIGATED SUGARCANE CROPS $^{1}$
}

\author{
VALDECI CALIXTO DA SILVA FILHO ${ }^{2 *}$, ADERSON SOARES DE ANDRADE JÚNIOR ${ }^{3}$, VALDENIR QUEIROZ \\ RIBEIRO $^{3}$, FRANCISCO DE BRITO MELO ${ }^{3}$, ALZENEIDE DA SILVA LOPES $^{2}$
}

\begin{abstract}
The objective of this study was to evaluate the distribution of $\mathrm{NO}_{3}{ }^{-}$and $\mathrm{K}^{+}$in the profile of soils cultivated with sugarcane crops, after application of different nitrogen $(\mathrm{N})$ and potassium $\left(\mathrm{K}_{2} \mathrm{O}\right)$ rates via subsurface drip fertigation, in Teresina, PI, Brazil. The experiment was conducted at the experimental area of Embrapa Meio-Norte, using a randomized block design with four replications. The treatments were arranged in split plots, with $\mathrm{N}+\mathrm{K}_{2} \mathrm{O}$ rates $\left(60+120,180+120,120+60,120+180\right.$, and $120+120 \mathrm{~kg} \mathrm{ha}^{-1}$ of $\mathrm{N}+\mathrm{K}_{2} \mathrm{O}$, respectively) in the plots, and soil layers $(0.0-0.2,0.2-0.4$, and $0.4-0.6 \mathrm{~m})$, for quantification of $\mathrm{NO}_{3}{ }^{-}$and $\mathrm{K}^{+}$ concentrations in the soil, in the subplots. The soil of the experimental area was a Typic Hapludult of sandyloam texture. The distribution of nitrate $\left(\mathrm{NO}_{3}{ }^{-}\right)$and potassium $\left(\mathrm{K}^{+}\right)$in the soil layers after the $\mathrm{N}+\mathrm{K}_{2} \mathrm{O}$ applications were evaluated. The $\mathrm{NO}_{3}{ }^{-}$and $\mathrm{K}^{+}$concentrations in soils under sugarcane crops in the plant crop cycle is higher at the beginning and at the end of the cycle, respectively. The $\mathrm{NO}_{3}{ }^{-}$and $\mathrm{K}^{+}$concentrations in the soil solution are dependent on the evaluation time, soil layer, and $\mathrm{N}$ and $\mathrm{K}_{2} \mathrm{O}$ rates applied via fertigation. The highest concentrations of $\mathrm{NO}_{3}^{-}\left(264 \mathrm{mg} \mathrm{L}^{-1}\right)$ and $\mathrm{K}^{+}(377 \mathrm{ppm})$ were found in the 0.0-0.2 $\mathrm{m}$ soil layer. No leaching of $\mathrm{NO}_{3}{ }^{-}$or $\mathrm{K}^{+}$to deepest soil layers $(>0.4 \mathrm{~m})$ was found.
\end{abstract}

Keywords: Nutrient. Depth. Ionic concentration.

\section{DINÂMICA DE NITRATO E POTÁSSIO EM PERFIL DE SOLO CULTIVADO COM CANA-DE- AÇÚCAR FERTIRRIGADA}

\begin{abstract}
RESUMO - Objetivou-se, nesse estudo, avaliar a distribuição de $\mathrm{NO}_{3}{ }^{-}$e $\mathrm{K}^{+}$no perfil do solo cultivado com cana-de-açúcar em resposta a doses de nitrogênio $(\mathrm{N})$ e potássio $\left(\mathrm{K}_{2} \mathrm{O}\right)$ aplicados via fertirrigação por gotejamento subsuperficial na microrregião de Teresina-PI. O experimento foi conduzido na área experimental da Embrapa Meio-Norte, Teresina - PI. Usou-se o delineamento experimental de blocos ao acaso, com quatro repetições. Os tratamentos foram arranjados em parcelas subdivididas, com as doses de $\mathrm{Ne}_{2} \mathrm{O}$, nas parcelas, e as profundidades de quantificação das concentrações de $\mathrm{NO}_{3}^{-}$e $\mathrm{K}^{+}$, nas subparcelas. $\mathrm{O}$ solo da área experimental é um Argissolo Vermelho Amarelo distrófico, textura franco-arenosa. Avaliou-se a distribuição de nitrato $\left(\mathrm{NO}_{3}{ }^{-}\right)$e potássio $\left(\mathrm{K}^{+}\right)$, nas camadas de $0-0.2 ; 0.2-0.4$ e $0.4-0.6 \mathrm{~m}$, em resposta a aplicação de cinco doses de $\mathrm{N}$ e de $\mathrm{K}_{2} \mathrm{O}\left(60+120 ; 180+120 ; 120+60 ; 120+180\right.$ e $120+120 \mathrm{~kg} \mathrm{ha}^{-1}$ de $\mathrm{N}^{2} \mathrm{~K}_{2} \mathrm{O}$, respectivamente). A distribuição da concentração de $\mathrm{NO}_{3}{ }^{-}$no cultivo de cana-de-açúcar, ciclo de cana planta, ocorre de forma mais intensa no início do ciclo, enquanto que a do $\mathrm{K}^{+}$ao final do ciclo. As concentrações de $\mathrm{NO}_{3}{ }^{-}$e $\mathrm{K}^{+}$na solução do solo são condicionadas às épocas de avaliação, profundidades e doses de $\mathrm{N}$ e $\mathrm{K}_{2} \mathrm{O}$ aplicadas via fertirrigação. As maiores concentrações de $\mathrm{NO}_{3}^{-}\left(264 \mathrm{mg} \mathrm{L}^{-1}\right)$ e $\mathrm{K}^{+}(377 \mathrm{ppm})$ apresentaram-se na profundidade $0,0-0,2 \mathrm{~m}$. Não houve lixiviação de $\mathrm{NO}_{3}{ }^{-}$e $\mathrm{K}^{+}$para a camada mais profunda do solo $(>0,4 \mathrm{~m})$.
\end{abstract}

Palavras-chave: Nutriente. Profundidade. Concentração iônica.

\footnotetext{
"Corresponding author

${ }^{1}$ Received for publication in $02 / 18 / 2019$; accepted in $09 / 27 / 2019$.

Paper extracted from the master's thesis of the first author.

${ }^{2}$ Postgraduate Program in Tropical Agronomy-Agriculture, Universidade Federal do Piauí, Teresina, PI, Brazil; valdecicalixto@yahoo.com.br - ORCID: 0000-0001-5752-1462, agro.neide@hotmail.com - ORCID: 0000-0002-6086-3567.

${ }^{3}$ Mid-North Agricultural Research Center, EMBRAPA, Teresina, PI, Brazil; aderson.andrade@embrapa.br - ORCID: 0000-0002-06191851, valdenir.queiroz@embrapa.br-ORCID: 0000-0002-9062-2529, francisco.brito@embrapa.br - ORCID: 0000-0002-4544-9261.
} 


\section{INTRODUCTION}

The use of traditional soil fertilization for sugarcane crops is common due to its practicality and lower technical requirement, which may lead to disordered applications. This practice is characterized by applications of high fertilizer rates at low frequencies, causing risk of nutrient leaching to areas with no root systems, especially nitrate $\left(\mathrm{NO}_{3}{ }^{-}\right)$and potassium $\left(\mathrm{K}^{+}\right)$(VITTI et al., 2005). Intensive and often disordered fertilizations with insufficient and unbalanced nutrients generate economic losses and aggravate possible environmental impacts, which is not in agreement with the principles of agronomic science (FREITAS et al., 2007).

Thus, the use of fertigation is recommended; this system allows a better control of the distribution of nutrients throughout the sugarcane cycle. Nutrient uptake by plants, such as sugarcane, is limited by soil, temperature, solar radiation, and precipitation (OLIVEIRA et al., 2011). The Brazilian northeastern coast presents rainfall concentrated within four months, thus, hindering the crops' productive capacity and the plants' efficiency in absorbing available soil water and nutrients (SANTOS et al., 2009).

$\mathrm{K}^{+}$is the most exported nutrient by sugarcane, reaching extraction of approximately $55 \%$ only by the culms (ROSSETTO et al., 2008). Oliveira et al. (2010) evaluated the exportation of nitrogen $(\mathrm{N})$ in sugarcane crops and found that this nutrient was one of the most exported, reaching extraction of $51 \%$ by the culms.

The $\mathrm{N}$ supply to sugarcane should be monitored considering its use by the plant, and nutrient loss through several processes, including nitrification. Silva et al. (2006) evaluated the N balance for $\mathrm{N}$-fertilizer recommendation and found large loss of ammonium because of the lack of rainfall after application and the high temperatures during fertilization, which reduced mineral $\mathrm{N}$ contents, nitrification, and, thus, the $\mathrm{N}$ availability to the sugarcane crop.

Part of the $\mathrm{NO}_{3}{ }^{-}$leachate to layers below 0.2 $\mathrm{m}$ is possibly partially absorbed by sugarcane plants, considering that a significant part of their root system can reach deep soil layers. According to Silva -Olaya, Cerre and Cerre (2017), 61\% of the root biomass of sugarcane plants is in the $0.0-0.02 \mathrm{~cm}$ soil layer, and Camargo et al. (2017) found that the effective depth of the sugarcane root system is at 0.6 $\mathrm{m}$. This context denotes the need for studies regarding the distribution of $\mathrm{NO}_{3}{ }^{-}$and $\mathrm{K}^{+}$in different layers of the soil profile after application of $\mathrm{N}$ and $\mathrm{K}$ fertilizers.

Losses of $\mathrm{NO}_{3}{ }^{-}$in the soil profile should be monitored, especially in intensive production systems with high use of nitrogen fertilizers, for the planning of measures that increase the use efficiency of the applied $\mathrm{N}$ focused on the management of an economically sustainable production system, with quality products and a minimal negative environmental impact (MENDES et al., 2015). $\mathrm{NO}_{3}{ }^{-}$ leaching increases depending on soil physical properties and use of intensive farming practices and high amount of water for irrigation (ANDRADE et al., 2009).

$\mathrm{K}^{+}$leaching is common because of rainfall events (ROSOLEM et al., 2003); this loss is due to its high solubility, which may result in unsatisfactory crop yields.

Therefore, the objective of this study was to evaluate the distribution of $\mathrm{NO}_{3}{ }^{-}$and $\mathrm{K}^{+}$in the profile of soils cultivated with sugarcane crops, after applications of different nitrogen $(\mathrm{N})$ and potassium $\left(\mathrm{K}_{2} \mathrm{O}\right)$ rates via subsurface drip fertigation, in Teresina, PI, Brazil.

\section{MATERIAL AND METHODS}

The experiment was conducted at the experimental area of the Brazilian Agricultural Research Corporation (Embrapa Meio-Norte), in Teresina, PI, Brazil $\left(5^{\circ} 5^{\prime} 211^{\prime \prime S}, 42^{\circ} 48^{\prime} 6^{\prime \prime} \mathrm{W}\right.$, and altitude of $72 \mathrm{~m}$ ). The region presents average air temperature of $27.6^{\circ} \mathrm{C}$ and annual average rainfall of $1,349 \mathrm{~mm}$. The climate of the region is $\mathrm{C} 1 \mathrm{sA}$ 'a', according to the Thornthwaite and Mather climate classification, characterized as dry sub-humid, megathermal, with moderate water surplus in the summer and a concentration of the potential evapotranspiration $(32.2 \%)$ from September to November (BASTOS; ANDRADE JÚNIOR, 2014).

A randomized block experimental design with four replications was used to evaluate the distribution of $\mathrm{NO}_{3}{ }^{-}$and $\mathrm{K}^{+}$in the soil profile. The treatments were arranged in split plots, with $\mathrm{N}+\mathrm{K}_{2} \mathrm{O}$ rates in the plots, and soil layers in the subplots.

The sugarcane variety RB 92579 (plant crop cycle) was used. This variety is recommended for irrigated crops and covers an expressive area in the Teresina microregion. The planting was done on June 06, 2014, using double-row spacing $(0.5 \mathrm{~m}$ between plant rows and $2.0 \mathrm{~m}$ between double rows), and 15 buds per linear meter. The soil was prepared with one plowing and one harrowing.

A subsurface drip irrigation system was used, with two meters between drip lines, drippers spaced $0.6 \mathrm{~m}$ apart, flow rate of $2.3 \mathrm{~L} \mathrm{~h}^{-1}$, and pressure of $200 \mathrm{kPa}$; the drip lines were buried $0.25 \mathrm{~m}$ deep in the center of the double rows.

The soil of the experimental area was classified as a Typic Hapludult (Argissolo Vermelho Amarelo distrófico) of a sandy-loam texture (MELO; ANDRADE JÚNIOR; PESSOA, 2014). The chemical and physical-hydrological properties of the $0.0-0.2,0.2-0.4$, and $0.4-0.6$ soil layers are presented in Table 1. 
V. C. SILVA FILHO et al.

Table 1. Chemical and physical-hydrological characterization of the soil the experimental area.

\begin{tabular}{|c|c|c|c|}
\hline \multirow{2}{*}{ Parameters } & \multicolumn{3}{|c|}{ Soil layer (m) } \\
\hline & $0.0-0.2$ & $0.2-0.4$ & $0.4-0.6$ \\
\hline & \multicolumn{3}{|c|}{ Chemical attributes } \\
\hline $\mathrm{pH} \mathrm{H} \mathrm{H}_{2} \mathrm{O}$ & 5.76 & 5.22 & 5.28 \\
\hline $\mathrm{OM}\left(\mathrm{g} \mathrm{kg}^{-1}\right)$ & 13.88 & 7.64 & 6.46 \\
\hline $\mathrm{P}\left(\mathrm{mg} \mathrm{dm}^{-3}\right)$ & 16.21 & 13.56 & 12.77 \\
\hline $\mathrm{H}+\mathrm{Al}\left(\mathrm{cmol}_{\mathrm{c}} \mathrm{dm}^{-3}\right)$ & 3.30 & 3.85 & 4.73 \\
\hline $\mathrm{Al}\left(\mathrm{cmol}_{\mathrm{c}} \mathrm{dm}^{-3}\right)$ & 0.07 & 0.95 & 1.27 \\
\hline $\mathrm{Ca}\left(\mathrm{cmol}_{\mathrm{c}} \mathrm{dm}^{-3}\right)$ & 1.21 & 0.38 & 0.42 \\
\hline $\mathrm{Mg}\left(\mathrm{cmol}_{\mathrm{c}} \mathrm{dm}^{-3}\right)$ & 0.69 & 0.11 & 0.10 \\
\hline $\mathrm{K}\left(\mathrm{cmol}_{\mathrm{c}} \mathrm{dm}^{-3}\right)$ & 0.23 & 0.07 & 0.12 \\
\hline $\mathrm{Na}\left(\mathrm{cmol}_{\mathrm{c}} \mathrm{dm}^{-3}\right)$ & 0.02 & 0.02 & 0.04 \\
\hline $\operatorname{CEC}\left(\mathrm{cmol}_{\mathrm{c}} \mathrm{dm}^{-3}\right)$ & 5.43 & 4.40 & 5.37 \\
\hline Sum of bases & 2.15 & 0.58 & 0.68 \\
\hline \multirow{2}{*}{ Base saturation (\%) } & 39.59 & 13.18 & 12.63 \\
\hline & \multicolumn{3}{|c|}{ Physical-hydrological attributes } \\
\hline Density $\left(\mathrm{mg} \mathrm{m}^{-3}\right)$ & 1.434 & 1.603 & 1.577 \\
\hline Sand $\left(\mathrm{g} \mathrm{kg}^{-1}\right)$ & 610 & 626 & 573 \\
\hline Silt $\left(\mathrm{g} \mathrm{kg}^{-1}\right)$ & 279 & 225 & 246 \\
\hline Clay $\left(\mathrm{g} \mathrm{kg}^{-1}\right)$ & 112 & 149 & 181 \\
\hline $\mathrm{FC}\left(\mathrm{m}^{3} \mathrm{~m}^{-3}\right)$ & 0.245 & 0.245 & 0.268 \\
\hline $\operatorname{PWP}\left(\mathrm{m}^{3} \mathrm{~m}^{-3}\right)$ & 0.06 & 0.08 & 0.12 \\
\hline
\end{tabular}

Soil samples collected before the lime application; $\mathrm{CEC}=$ cation exchange capacity; $\mathrm{FC}=$ field capacity $(6 \mathrm{kPa}) ; \mathrm{PWP}=$ permanent wilting point $(1,500 \mathrm{kPa})$.

Based on studies about soil fertilization for sugarcane crops (ANDRADE JÚNIOR et al., 2010; COELHO et al., 2014; FLORES et al., 2012; JORIS, 2015), five treatments were established, composed of $\mathrm{N}$ (urea) $+\mathrm{K}_{2} \mathrm{O}$ (potassium chloride) at rates of $60+120$ (T1); 180+120 (T2); 120+60 (T3); 120+180 (T4), and $120+120$ (T5) $\mathrm{kg} \mathrm{ha}^{-1}$.
Fertigation with $\mathrm{N}$ and $\mathrm{K}_{2} \mathrm{O}$ started on August 04, 2014 (60 days after planting) and lasted six months (August 2014 to January 2015); it was applied once a week, totaling 24 applications throughout the sugarcane crop cycle. The application of the treatments throughout the crop cycle was divided according to the distribution presented in table 2 .

Table 2. Monthly applications (\%) of $\mathrm{N}$ and $\mathrm{K}_{2} \mathrm{O}$ rates throughout the sugarcane crop cycle.

\begin{tabular}{ccc}
\hline Month/Year & $\mathrm{N}$ & $\mathrm{K}_{2} \mathrm{O}$ \\
\hline Aug/2014 & $15 \%$ & $10 \%$ \\
Sep/2014 & $20 \%$ & $15 \%$ \\
Oct $/ 2014$ & $25 \%$ & $20 \%$ \\
Nov/2014 & $20 \%$ & $25 \%$ \\
Dec/2014 & $15 \%$ & $20 \%$ \\
Jan/2015 & $5 \%$ & $10 \%$ \\
\hline
\end{tabular}

$30 \%$ of the recommended $\mathrm{K}_{2} \mathrm{O}$ rate was applied directly to the soil at planting.

Based on the soil chemical analysis, $2 \mathrm{Mg} \mathrm{ha}^{-1}$ of lime (total neutralizing power of $90 \%$ ) was applied at 90 days before planting. The $\mathrm{P}_{2} \mathrm{O}_{5}$ was applied at a rate of $100 \mathrm{~kg} \mathrm{ha}^{-1}-30 \%$ at planting (triple superphosphate), and $70 \%$ via fertigation (monoammonium phosphate) distributed monthly. The micronutrients applied were boric acid $(4.5 \mathrm{~kg}$ $\left.\mathrm{ha}^{-1}\right)$, zinc oxide $\left(7 \mathrm{~kg} \mathrm{ha}^{-1}\right)$, copper oxide $\left(6 \mathrm{~kg} \mathrm{ha}^{-1}\right)$, manganese oxide $\left(11 \mathrm{~kg} \mathrm{ha}{ }^{-1}\right)$, and sodium molybdate (1 $\left.\mathrm{kg} \mathrm{ha} \mathrm{ha}^{-1}\right)$; they were applied via fertigation split in six applications during the crop cycle.

The $\mathrm{N}$ and $\mathrm{K}_{2} \mathrm{O}$ rates were applied using a hydraulic injector (positive displacement pump).
The fertigation flow to the plots was turned on and off by hydraulic registers installed at the beginning of the row of each experimental plot to control the irrigation depths and $\mathrm{N}$ and $\mathrm{K}_{2} \mathrm{O}$ rates.

The irrigation depth was established based on crop evapotranspiration (ETc), using the reference evapotranspiration (ETo) estimated by the PenmanMonteith method, based on daily climatic data from an automatic weather station installed at the site (Embrapa Meio-Norte) and on crop coefficients of sugarcane established for the region (ANDRADE JÚNIOR et al., 2017). The irrigation application frequency was three times a week (Mondays, Wednesdays, and Fridays). 
The plots were $60 \mathrm{~m}^{2}$ and consisted of three 10 -meter double rows. The area of the plot evaluated for $\mathrm{NO}_{3}{ }^{-}$and $\mathrm{K}^{+}$concentration in the soil solution consisted of two plant rows, from where the soil samples were taken for analysis. Simple soil samples $(\sim 0.5 \mathrm{~kg})$ were collected at 6 different times (105, $122,194,227,276$, and 326 days after planting DAP) in each replication and soil depth (0.0-0.2, 0.20.4 , and 0.4-0.6 m), using a Dutch auger at $0.2 \mathrm{~m}$ from the dripper line, totaling 360 samples. This sampling method was used to collect soil samples from both the sugarcane root system region and near the region where the fertilizers were applied.

The soil samples were, then, disaggregated and passed through a 2-mm mesh sieve to reduce the size of the soil particles. The disaggregated soil samples were subjected to a saturated paste preparation, following the methodology of Richards (1954). A sub-sample of $0.25 \mathrm{~kg}$ was taken from each sample and placed in a $0.5 \mathrm{~L}$ beaker. Then, 100 $\mathrm{mL}$ of distilled water was slowly added with the aid of a wash bottle, always homogenizing the soil with a stainless-steel spatula until the paste became saturated.
The soil solution extracts were, then, removed from the saturated paste using a filter paper placed on a porcelain Büchner funnel coupled to a beaker, which was set to a pressure of $-80 \mathrm{kPa}$ generated by a vacuum pump. A $15-\mathrm{mL}$ aliquot of the solution extract was taken from each sub-sample and placed in 50-mL capped glass containers for subsequent determination of $\mathrm{NO}_{3}{ }^{-}$and $\mathrm{K}^{+}$ion concentrations, which was made according to the Kjeldahl $\left(\mathrm{NO}_{3}{ }^{-}\right)$ and photometry $\left(\mathrm{K}^{+}\right)$methods (SILVA et al., 2010).

The results regarding the dynamics of the $\mathrm{NO}_{3}{ }^{-}$and $\mathrm{K}^{+}$ions in the soil profile were subjected to analysis of variance, and the means were compared by the Tukey's test $(p>0.05)$. Statistical analyses were done using the SAS 14.1 program (SAS INSTITUTE, 2016).

\section{RESULTS AND DISCUSSION}

The cumulative monthly data of ETc, applied irrigation depth (ID), rainfall (R), and sum of ID and $\mathrm{R}$ throughout the experimental period are presented in Figure 1.

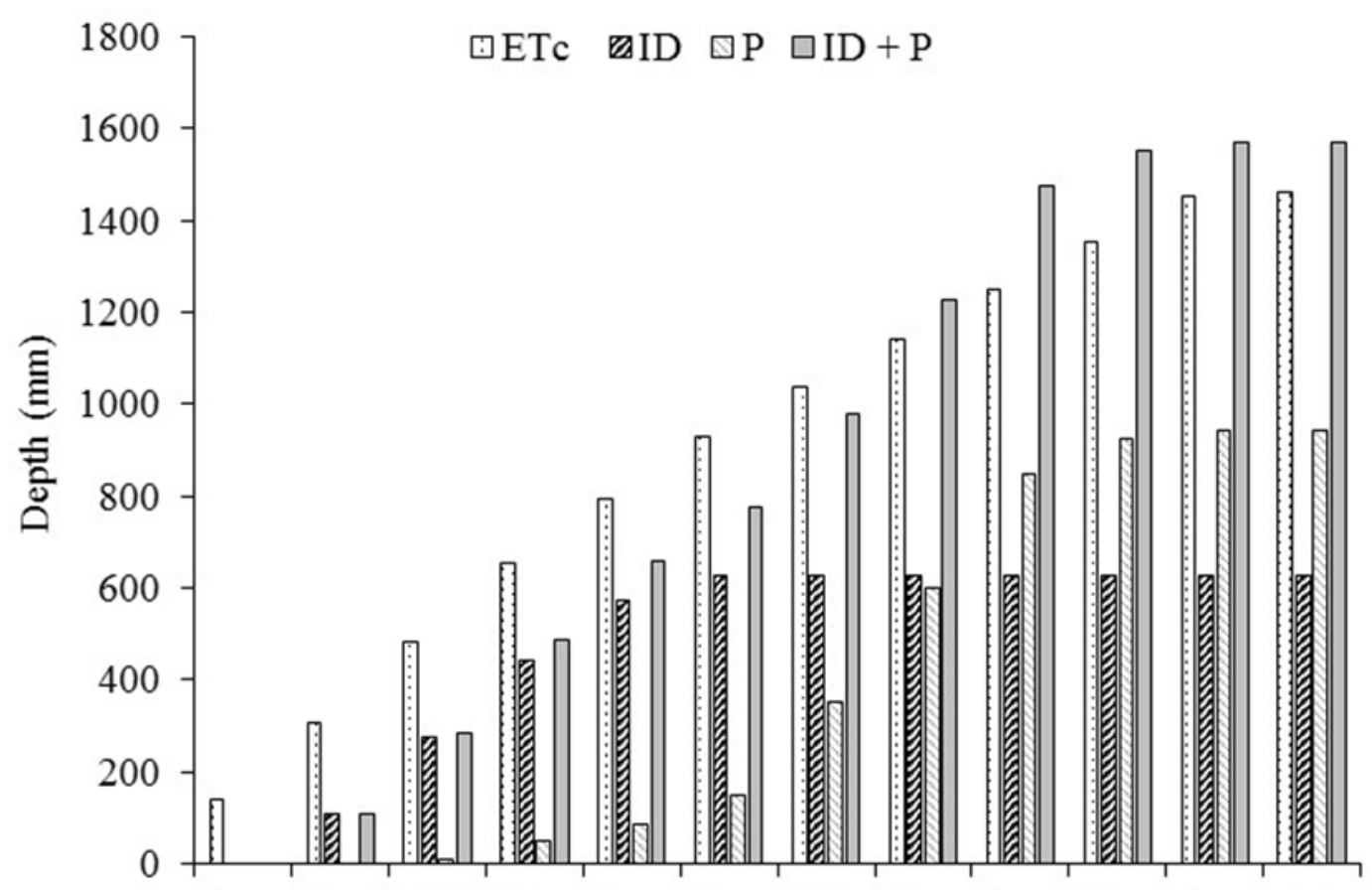

Aug. Sep. Oct. Nov. Dec. Jan. Feb. Mar. Apr. May Jun. Jul.

\section{Months}

Figure 1. Cumulative monthly data of ETc, applied irrigation depth (ID), precipitation (P), and sum of ID and $P$ throughout the experimental period.

The sugarcane water requirement was fully met by the application of ID+R during the experiment period. The total ID used was $657.0 \mathrm{~mm}$ and the total rainfall measured was $849.2 \mathrm{~mm}$, totaling $1,506.2 \mathrm{~mm}$. The water requirement of sugarcane plants is 1,500 to $2,500 \mathrm{~mm}$ (MARIN,
2019), which must be evenly distributed during their vegetative development (BRASIL, 2016); and the amount of water needed for the maximum production potential of the crop is 1,200 to 1,300 mm (DOORENBOS; KASSAM, 2000). Therefore, this was not a limiting factor for the expression of 
the crop productive potential under the conditions of the present experiment.

The analysis of variance for the $\mathrm{NO}_{3}{ }^{-}$ concentrations over the three soil layers and six sampling times throughout the sugarcane cycle, after application of different $\mathrm{N}$ rates via subsurface drip fertigation, is shown in Table 3.

Table 3. Analysis of variance for nitrate $\left(\mathrm{NO}_{3}{ }^{-}\right)$concentration $\left(\mathrm{mg} \mathrm{L}^{-1}\right)$ in three soil layers collected at six different times (days after planting - DAP) during the sugarcane crop cycle.

\begin{tabular}{|c|c|c|c|c|}
\hline Source of variation & DF & 105 DAP & 122 DAP & 194 DAP \\
\hline Block & 3 & $2113.91^{* *}$ & $690.19^{* *}$ & $1414.75^{* *}$ \\
\hline Treatments (T) & 4 & $3652.47^{* *}$ & $2797.81^{* *}$ & $2274.44^{* *}$ \\
\hline Error (a) & 12 & $1366.31^{* *}$ & $334.00^{* *}$ & $742.58^{* *}$ \\
\hline Soil layer (L) & 2 & $8662.48^{* *}$ & $2622.05^{* *}$ & $5616.68^{* *}$ \\
\hline $\mathrm{T} * \mathrm{~L}$ & 8 & $659.53^{* *}$ & $1923.75^{* *}$ & $612.64^{* *}$ \\
\hline Error (b) & 30 & 38.63 & 95.77 & 38.10 \\
\hline CV (a) $\%$ & --- & 15.34 & 15.34 & 26.09 \\
\hline CV (b) $\%$ & --- & 16.84 & 24.65 & 17.74 \\
\hline Source of variation & DF & 227 DAP & 276 DAP & 326 DAP \\
\hline Block & 3 & $1550.20^{\mathrm{ns}}$ & $1143.50^{*}$ & $13781.84^{* * *}$ \\
\hline Treatments $(\mathrm{T})$ & 4 & $24858.20^{* *}$ & $1429.68^{* *}$ & $24113.61^{* *}$ \\
\hline Error (a) & 12 & $8447.86^{* *}$ & $3403.60^{* *}$ & $10178.96^{* *}$ \\
\hline Soil layer(L) & 2 & $18907.34^{* *}$ & $10505.76^{* *}$ & $13069.83^{*}$ \\
\hline $\mathrm{T} * \mathrm{~L}$ & 8 & $1310.52^{*}$ & $704.46^{*}$ & $5078.70^{*}$ \\
\hline Error (b) & 30 & 549.66 & 197.21 & 1913.41 \\
\hline CV (a) $\%$ & --- & 14.96 & 45.99 & 18.60 \\
\hline $\mathrm{CV}$ (b) $\%$ & --- & 27.22 & 33.21 & 24.20 \\
\hline
\end{tabular}

$\mathrm{DAP}=$ days after planting; $\mathrm{DF}=$ degrees of freedom; $\mathrm{CV}=$ coefficient of variation; $\mathrm{ns}=$ not significant $(p>0.05),{ }^{*}=$ significant at $0.05 \geq p>0.01, * *=$ significant at $p \leq 0.01$.

The interaction between treatments and soil layers was significant $(p<0.05)$ for $\mathrm{NO}_{3}^{-}$ concentrations in all evaluated sampling times, indicating that $\mathrm{NO}_{3}{ }^{-}$concentration varied in the soil layers in each sampling time depending on the $\mathrm{N}$ rates applied.

The highest $\mathrm{NO}_{3}{ }^{-}$concentrations in the 0.0 $0.2 \mathrm{~m}$ soil layer (Table 4) were found at $227 \mathrm{DAP}$ (culm growth stage), despite the reduction from $25 \%$ to $20 \%$ in the rates of $\mathrm{N}$ applied during this period (Table 2). The highest $\mathrm{NO}_{3}{ }^{-}$concentration was found at 326 DAP (maturation stage and harvest), denoting that sugarcane extracted less $\mathrm{NO}_{3}^{-}$from the soil during this period, since the $\mathrm{N}$ demand of sugarcane plant decreases significantly in this stage (PENATTI, 2013). Joris (2015) evaluated $\mathrm{NO}_{3}{ }^{-}$concentrations in different layers of soils cultivated with sugarcane crops, after application of different $\mathrm{N}$ rates, and found increases in $\mathrm{NO}_{3}{ }^{-}$concentration in the 0.1-0.2 $\mathrm{m}$ soil layer as the sampling time increased, which was confirmed by the results obtained in the present study.

Regarding the $0.0-0.2 \mathrm{~m}$ soil layer, when the plants were at 105 DAP (establishment stage), higher $\mathrm{NO}_{3}{ }^{-}$concentrations were found in the treatments $\mathrm{T} 2$ $\left(180 \mathrm{~kg} \mathrm{ha}^{-1} \mathrm{~N}+120 \mathrm{~kg} \mathrm{ha}^{-1} \mathrm{~K}_{2} \mathrm{O}\right)$ and $\mathrm{T} 4(120 \mathrm{~kg}$ $\mathrm{ha}^{-1} \mathrm{~N}+180 \mathrm{~kg} \mathrm{ha}^{-1} \mathrm{~K}_{2} \mathrm{O}$ ). Similar result was found at 194 DAP (tillering stage), when the treatments received the highest percentage of $\mathrm{N}$ rates. However, these higher $\mathrm{NO}_{3}{ }^{-}$concentrations in $\mathrm{T} 2$ and $\mathrm{T} 4$ were not constant throughout the sugarcane crop cycle, due to lower nitrogen uptake by the crop at initial vegetative stages. Joris (2015) evaluated applications of different $\mathrm{N}$ rates on sugarcane crops to evaluate $\mathrm{NO}_{3}{ }^{-}$concentrations in the soil profile and found similar results: the application of the highest $\mathrm{N}$ rates $\left(180 \mathrm{~kg} \mathrm{ha}^{-1}\right)$ did not result in the highest $\mathrm{NO}_{3}{ }^{-}$ concentrations $\left(16 \mathrm{mg} \mathrm{kg}^{-1}\right)$, which was reached with application of lower $\mathrm{N}$ rates $\left(120 \mathrm{~kg} \mathrm{ha}^{-1}\right)$. Considering the $0.0-0.2 \mathrm{~m}$ soil layer, significantly higher $\mathrm{NO}_{3}{ }^{-}$concentration was found only for the treatment T4, when the plants were at 194 DAP; whereas at $227 \mathrm{DAP}$, higher $\mathrm{NO}_{3}^{-}$concentrations were found for T4 and T5 $\left(120 \mathrm{~kg} \mathrm{ha}^{-1}\right.$ of $\mathrm{N}+120 \mathrm{~kg}$ $\mathrm{ha}^{-1}$ of $\mathrm{K}_{2} \mathrm{O}$ ).

Regarding the $0.2-0.4 \mathrm{~m}$ soil layer, the $\mathrm{NO}_{3}{ }^{-}$ concentrations found from 105 DAP to 194 DAP were lower than those found in the $0.0-0.2 \mathrm{~m}$. This result was due to the root system development and performance in this soil layer at 122 DAP (sugarcane establishment stage) and to the higher initial nutrient consumption of the plants during this period. The $\mathrm{NO}_{3}{ }^{-}$concentration in this layer increased from 227 DAP (culm growth stage), presenting the highest values at the last evaluation (326 DAP). Coelho et al. (2014) evaluated $\mathrm{NO}_{3}^{-}$concentrations in the soil profile of fertigated soils and found similar results; they reported increases in mean $\mathrm{NO}_{3}{ }^{-}$concentrations in the soil solution at the $0.0-0.30 \mathrm{~m}$ layer from the beginning of the crop cycle, which lasted for 11 months. 
V. C. SILVA FILHO et al.

Table 4. Nitrate $\left(\mathrm{NO}_{3}^{-}\right)$concentrations $\left(\mathrm{mg} \mathrm{L}^{-1}\right)$ in the $0.0-0.2,0.2-0.4$, and $0.4-0.6 \mathrm{~m}$ soil layers after application of different $\mathrm{N}$ rates, evaluated at six sampling times (days after planting - DAP).

\begin{tabular}{|c|c|c|c|c|c|c|}
\hline $\begin{array}{c}\text { Treatments } \\
\mathrm{N}+\mathrm{K}_{2} \mathrm{O} \\
\left(\mathrm{kg} \mathrm{ha}^{-1}\right)\end{array}$ & 105 DAP & 122 DAP & 194 DAP & 227 DAP & 276 DAP & 326 DAP \\
\hline & \multicolumn{6}{|c|}{$0.0-0.2 \mathrm{~m}$ soil layer } \\
\hline $60+120$ & $50 \mathrm{~b}$ & $39 \mathrm{~b}$ & $52 \mathrm{~b}$ & $63 \mathrm{~b}$ & $75 \mathrm{a}$ & $195 \mathrm{a}$ \\
\hline $180+20$ & $83 \mathrm{a}$ & $40 \mathrm{~b}$ & $57 \mathrm{~b}$ & $92 \mathrm{~b}$ & $71 \mathrm{a}$ & $199 \mathrm{a}$ \\
\hline $120+60$ & $55 \mathrm{~b}$ & $80 \mathrm{a}$ & $40 \mathrm{~b}$ & $63 \mathrm{~b}$ & $57 \mathrm{a}$ & $208 \mathrm{a}$ \\
\hline $120+80$ & $88 \mathrm{a}$ & $66 \mathrm{a}$ & $74 \mathrm{a}$ & $170 \mathrm{a}$ & $62 \mathrm{a}$ & $184 \mathrm{a}$ \\
\hline $120+120$ & $18 \mathrm{c}$ & $39 \mathrm{~b}$ & $46 \mathrm{~b}$ & $147 \mathrm{a}$ & $77 \mathrm{a}$ & $264 \mathrm{a}$ \\
\hline \multicolumn{7}{|c|}{$0.2-0.4 \mathrm{~m}$ soil layer } \\
\hline $60+120$ & $32 \mathrm{~b}$ & $22 b$ & $7 \mathrm{~b}$ & $74 \mathrm{~b}$ & $40 \mathrm{a}$ & $134 \mathrm{~b}$ \\
\hline $180+20$ & $47 \mathrm{a}$ & $37 \mathrm{~b}$ & $64 \mathrm{a}$ & $64 \mathrm{~b}$ & $36 \mathrm{a}$ & $160 \mathrm{~b}$ \\
\hline $120+60$ & $36 \mathrm{~b}$ & $78 \mathrm{a}$ & $22 \mathrm{~b}$ & $74 b$ & $32 \mathrm{a}$ & $183 \mathrm{~b}$ \\
\hline $120+80$ & $55 \mathrm{a}$ & $19 \mathrm{~b}$ & $22 b$ & $115 b$ & $36 \mathrm{a}$ & $109 \mathrm{~b}$ \\
\hline $120+120$ & $28 \mathrm{~b}$ & $17 \mathrm{~b}$ & $21 \mathrm{~b}$ & $177 \mathrm{a}$ & $14 \mathrm{a}$ & $258 \mathrm{a}$ \\
\hline \multicolumn{7}{|c|}{$0.4-0.6 \mathrm{~m}$ soil layer } \\
\hline $60+120$ & $27 \mathrm{a}$ & $44 \mathrm{~b}$ & $6 b$ & $20 \mathrm{~b}$ & $44 \mathrm{a}$ & $66 \mathrm{~b}$ \\
\hline $180+20$ & $27 \mathrm{a}$ & $7 \mathrm{c}$ & $48 \mathrm{a}$ & $8 \mathrm{~b}$ & $57 \mathrm{a}$ & $207 \mathrm{a}$ \\
\hline $120+60$ & $35 \mathrm{a}$ & $20 \mathrm{bc}$ & $15 \mathrm{~b}$ & $20 \mathrm{~b}$ & $17 \mathrm{a}$ & $131 \mathrm{~b}$ \\
\hline $120+80$ & $23 a$ & $71 \mathrm{a}$ & $23 \mathrm{~b}$ & $100 \mathrm{a}$ & $13 \mathrm{a}$ & $180 \mathrm{a}$ \\
\hline $120+120$ & $14 \mathrm{~b}$ & $16 \mathrm{c}$ & $24 b$ & $106 \mathrm{a}$ & $2 \mathrm{a}$ & $232 \mathrm{a}$ \\
\hline
\end{tabular}

Means followed by different letters in the columns are different by the Tukey's test at $5 \%$ probability.

The $\mathrm{NO}_{3}^{-}$concentrations found in treatments $\mathrm{T} 1\left(60 \mathrm{~kg} \mathrm{ha}^{-1} \mathrm{~N}+120 \mathrm{~kg} \mathrm{ha}^{-1} \mathrm{~K}_{2} \mathrm{O}\right)$ and $\mathrm{T} 2$ were significantly different at 194 DAP, presenting the lowest and highest $\mathrm{NO}_{3}{ }^{-}$concentrations, respectively. These treatments received the lowest and highest $\mathrm{N}$ rates, respectively, in this period, which explains the differences in $\mathrm{NO}_{3}{ }^{-}$concentrations. The highest $\mathrm{NO}_{3}{ }^{-}$ concentrations in the $0.2-0.4 \mathrm{~m}$ soil layer were found at 326 DAP; despite the reduction in $\mathrm{N}$ rates applied in this period, the values were higher because of the greater rainfall volumes occurring during this period and decreases in $\mathrm{N}$ consumption by the sugarcane plants (FRANCO et al., 2008), resulting in more available $\mathrm{NO}_{3}{ }^{-}$in the soil solution.

Regarding the 0.4-0.6 m soil layer, the $\mathrm{NO}_{3}^{-}$ concentrations were higher at $326 \mathrm{DAP}$, which was a similar result to those found for the 0.0-0.2 e 0.2-0.4 m. Studies on $\mathrm{NO}_{3}{ }^{-}$quantification at the end of the crop cycle of sugarcane crops under conventional management conditions (without constant soil coverage) showed that the contribution of nitrogen fertilizers to the total $\mathrm{N}$ absorbed by sugarcane is low $(10 \%$ to $16 \%)$ at this final stage (GAVA et al., 2001; TRIVELIN; VICTORIA; RODRIGUES, 1995; FRANCO et al., 2008). A higher $\mathrm{N}$ consumption at initial crop stages and a lower $\mathrm{NO}_{3}{ }^{-}$concentration in the soil were confirmed at 122 DAP, when the treatment $\mathrm{T} 2$ (highest $\mathrm{N}$ rate) resulted in the lowest $\mathrm{NO}_{3}{ }^{-}$concentrations. However, at 194 DAP, T2 presented higher $\mathrm{NO}_{3}{ }^{-}$concentrations in the soil than T3, T4, and T5. The plants were over half of their cycle at 194 DAP, with decreasing demand for N; thus, the results are in agreement with those of Franco et al. (2011), who evaluated the ${ }^{15} \mathrm{~N}$ use efficiency by sugarcane ratoon crop and found that after fertilization, at 30-60 DAP (initial stage of the crop cycle), the sugarcane plants absorbed practically all $\mathrm{N}$ accumulated during the whole crop cycle.

Higher $\mathrm{NO}_{3}{ }^{-}$concentrations were expected in the $0.4-0.6 \mathrm{~m}$ soil layer because of the leaching process. However, no significant difference in $\mathrm{NO}_{3}$ concentrations was found when compared to the other evaluated layers. This denotes the efficiency of the fertigation and subsurface irrigation system. The results confirm those found by Gil et al. (2008), who reported that subsurface drip irrigation presents high uniformity of water application, reducing the percolation of $\mathrm{NO}_{3}^{-}$.

Despite the proportionally lower nutrient rates applied, the highest $\mathrm{NO}_{3}{ }^{-}$concentrations in the three evaluated soil layers were found in the last evaluation times. Franco et al. (2011) evaluated N fertilization in sugarcane and found higher $\mathrm{N}$ extraction at the beginning of crop cycle, usually up to 90 days, due to a subsequent decrease in the crop $\mathrm{N}$ demand.

Coelho et al. (2014) evaluated mean $\mathrm{NO}_{3}$ concentrations in profiles of fertigated soils and found increases throughout 11 months in depths of 0.3 and $06 \mathrm{~m}$, with no differences between these soil depths. Contrastingly, significant different $\mathrm{NO}_{3}$ concentrations was found in the present study for the evaluated soil layers $(0.0-0.2,0.2-0.4$, and $0.4-0.6$ $\mathrm{m})$.

Oliveira et al. (2001) evaluated the effect of the application of different $\mathrm{N}$ rates on the leaching of $\mathrm{NO}_{3}{ }^{-}$in an Oxisol (Latossolo Amarelo) cultivated 
with sugarcane crops and found differences in $\mathrm{NO}_{3}^{-}$ concentrations in the soil solution at depths of 0.3 , 0.6 , and $0.9 \mathrm{~m}$ according to the treatments and sampling times, and found increases in $\mathrm{NO}_{3}{ }^{-}$contents in all evaluated soil layers as the $\mathrm{N}$ rates applied was increased, which is in agreement with the results found in the present study. These results denote the proportionality between $\mathrm{N}$ application and $\mathrm{NO}_{3}{ }^{-}$ concentrations; as in the evaluation at 197 DAP, when the treatment $\mathrm{T} 2$ received the highest $\mathrm{N}$ rate and presented the highest $\mathrm{NO}_{3}$ concentrations in the $\left.0.2-0.4 \mathrm{~m} \mathrm{(63.9} \mathrm{mg} \mathrm{L}^{-1}\right)$ and $0.4-0.6 \mathrm{~m}\left(47.68 \mathrm{mg} \mathrm{L}^{-1}\right)$ soil layers (Table 4).
According to Oliveira et al. (2001), differences in $\mathrm{NO}_{3}{ }^{-}$concentrations over time and soil depths can be attributed to rainwater percolation. The sum of the rainfall depths recorded and the irrigation depths applied was higher $(1,500.02 \mathrm{~mm})$ in June (Figure 1).

The analysis of variance for $\mathrm{K}^{+}$ concentrations in the soil layers at the six sampling times throughout the sugarcane crop cycle is shown in Table 5. This analysis showed significant difference between treatments and soil layers in all evaluation times, showing that the soil depth is also a significant factor for $\mathrm{K}^{+}$distribution.

Table 5. Summary of analysis of variance for potassium ( $\mathrm{ppm}$ ) in three soil layers, evaluated at six sampling times (days after planting - DAP) throughout the sugarcane crop.

\begin{tabular}{|c|c|c|c|c|}
\hline Source of variation & DF & 105 DAP & 122 DAP & 194 DAP \\
\hline Block & 3 & $216.84^{*}$ & $17367.68^{* *}$ & $5581.00^{* *}$ \\
\hline Treatments (T) & 4 & $502.11^{* *}$ & $86090.43^{* *}$ & $6598.48^{* *}$ \\
\hline Error (a) & 12 & $146.59^{* *}$ & $16944.58^{* *}$ & $1446.38^{* *}$ \\
\hline Soil layers (L) & 2 & $2708.36^{* *}$ & $1581.43^{* *}$ & $6736.81^{* *}$ \\
\hline $\mathrm{T}^{*} \mathrm{~L}$ & 8 & $198.75^{* *}$ & $10690.65^{* *}$ & $1090.86^{* *}$ \\
\hline Error (b) & 30 & 49.15 & 222.86 & $183.20^{* *}$ \\
\hline $\mathrm{CV}$ (a) $\%$ & --- & 14.96 & 9.44 & 16.07 \\
\hline CV (b) $\%$ & --- & 26.00 & 27.43 & 17.15 \\
\hline Source of variation & $\overline{\mathrm{DF}}$ & $227 \mathrm{DAP}$ & $276 \mathrm{DAP}$ & $326 \mathrm{DAP}$ \\
\hline Block & 3 & $5 \overline{5} 1.54^{*-}$ & $71.32^{* * 5}$ & $84.37^{7 \pi}$ \\
\hline Treatments $(\mathrm{T})$ & 4 & $241.02^{\mathrm{ns}}$ & $50.86^{* *}$ & $123.50^{* *}$ \\
\hline Error (a) & 12 & $400.09^{*}$ & $34,43^{* *}$ & $60.23^{* *}$ \\
\hline Soil layers(L) & 2 & $3143.00^{* *}$ & $32.57^{* *}$ & $161.08^{* *}$ \\
\hline $\mathrm{T}^{*} \mathrm{~L}$ & 8 & $100.11^{* *}$ & $2.09^{\mathrm{ns}}$ & $15.80^{\mathrm{ns}}$ \\
\hline Error (b) & 30 & 130.11 & 3.28 & 7.40 \\
\hline CV (a) $\%$ & --- & 18.52 & 26.86 & 19.10 \\
\hline $\mathrm{CV}$ (b) $\%$ & --- & 31.69 & 24.82 & 20.09 \\
\hline
\end{tabular}

$\mathrm{n} . \mathrm{s}=$ not significant $(\mathrm{p}>0.05), *=$ significant at $0.05 \geq \mathrm{p}>0.01, * *=$ significant at $\mathrm{p} \leq 0.01 ; \mathrm{DF}=$ degrees of freedom; $\mathrm{CV}=$ coefficient of variation.

The interaction between treatments and soil layers was significant $(\mathrm{p}<0.05)$ at $105,122,194$, and 227 DAP, indicating variations in $\mathrm{K}^{+}$concentrations throughout the soil profile in each sampling time according to the $\mathrm{K}_{2} \mathrm{O}$ rates.

The treatment $\mathrm{T} 4$ had the highest $\mathrm{K}_{2} \mathrm{O}$ rate and presented the highest $\mathrm{K}^{+}$concentrations in the 0.0-0.2 $\mathrm{m}$ layer in four of the six evaluation times (Table 6). The significantly different $\mathrm{K}^{+}$ concentrations denote their proportional response to $\mathrm{K}_{2} \mathrm{O}$ application, mainly considering the $\mathrm{K}^{+}$increases in the soil solution between 105 and 122 DAP (sprouting and establishment stages). Flores et al. (2012) evaluated the $\mathrm{K}^{+}$distribution in soils under sugarcane crops and found similar results, with $\mathrm{K}_{2} \mathrm{O}$ applications affecting the $\mathrm{K}^{+}$concentration in the soil solution of the surface layer the $\mathrm{K}^{+}$concentration in the soil solution increased in the $0.0-0.2 \mathrm{~m}$ layer as the $\mathrm{K}_{2} \mathrm{O}$ rates were increased.

Increases in the $\mathrm{K}^{+}$concentrations in the soil surface layer as the $\mathrm{K}_{2} \mathrm{O}$ rates are increased were expected; the loss of $\mathrm{K}^{+}$by leaching is small in clayey soils with high cation exchange capacity (CEC) (MIELNICZUK, 1982).

T2 presented a high $\mathrm{K}^{+}$concentration $(377$ ppm) in the $0.0-0.2 \mathrm{~m}$ soil layer at $122 \mathrm{DAP}$. This result can be explained by the higher $\mathrm{K}_{2} \mathrm{O}$ rate applied at 105 and 122 DAP (sprouting and establishment stages). Moreover, this soil layer presented almost 2 -fold the $\mathrm{K}^{+}$concentration $(0.23$ cmolc $\mathrm{dm}^{-3}$ ) when compared to the 0.4-0.6 m layer $\left(0.12 \mathrm{cmolc}^{-3}\right)$, and more than 3 -fold that of the $0.2-0.4 \mathrm{~m}$ layer $\left(0.7\right.$ cmolc $\left.\mathrm{dm}^{-3}\right)$ (Table 1$)$. The experimental error may have affected this result, considering the number of samples collected (60 per evaluation time)

The highest $\mathrm{K}^{+}$concentrations were found at the first evaluation times $(105,122$, and 194 DAP) and the lowest at the last ones $(227,276,326$ DAP) in all evaluated soil layers. Thus, the $\mathrm{K}^{+}$ consumption in the early stages of the sugarcane crop cycle is lower than in the final stages. Vitti et 
al. (2005) recommended $\mathrm{K}_{2} \mathrm{O}$ fertilization at higher rates before the sugarcane crop canopy closure because of its high consumption at final stages, as observed in the last evaluations for all soil layers, with decreases in $\mathrm{K}^{+}$concentrations due to the higher consumption of $\mathrm{K}^{+}$by the sugarcane plants.

Table 6. Potassium concentration (ppm) in the $0.0-0.2,0.2-0.4$, and $0.4-0.6 \mathrm{~m}$ soil layers after application of different $\mathrm{K}_{2} \mathrm{O}$ rates, evaluated at six sampling times (days after planting - DAP).

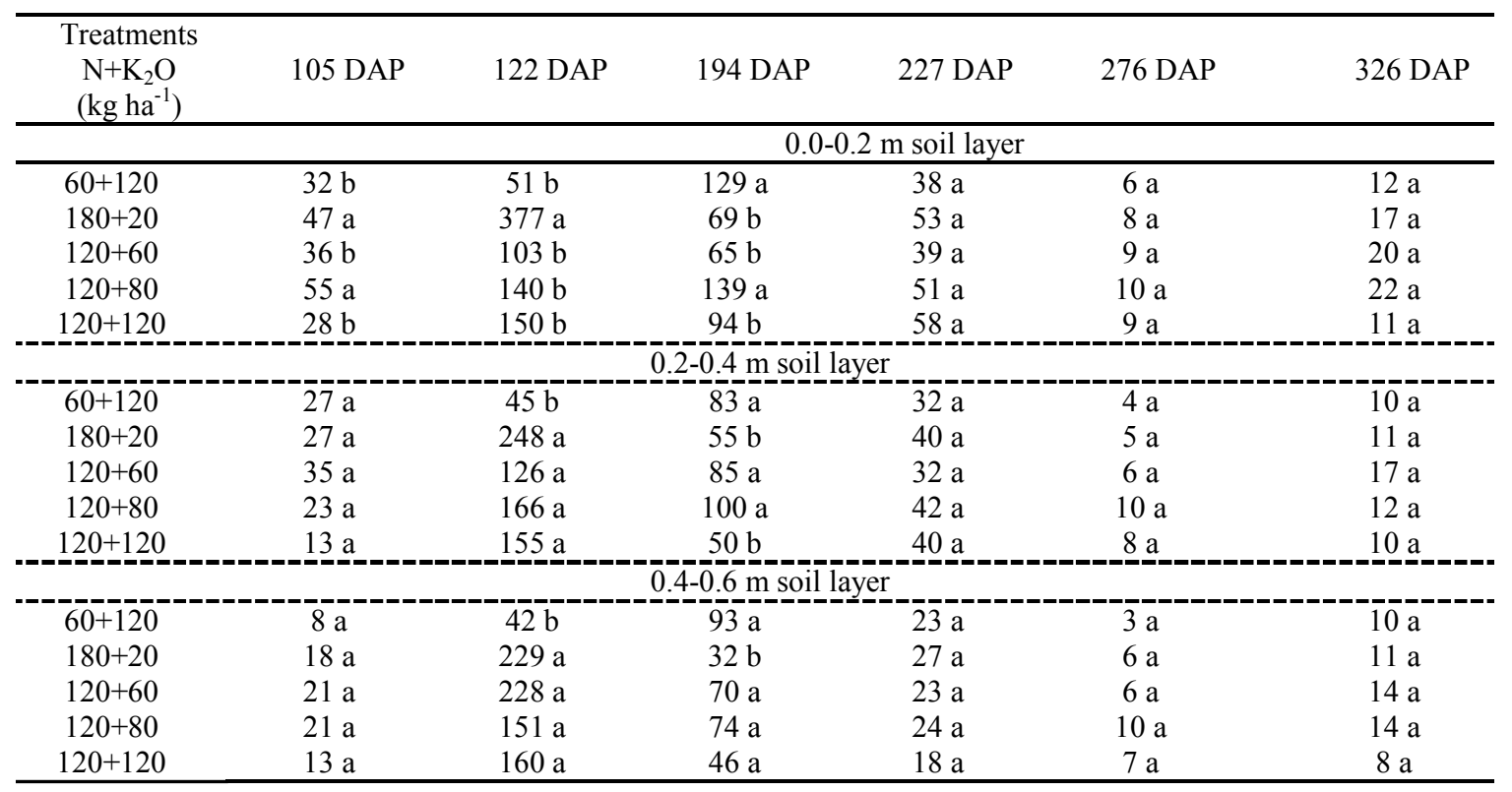

Means followed by different letters in the columns are different by the Tukey's test at $5 \%$ probability.

The treatment $\mathrm{T} 4$, which received the highest $\mathrm{K}_{2} \mathrm{O}$ rate, presented the highest $\mathrm{K}^{+}$concentrations in the $0.2-0.4 \mathrm{~m}$ soil layer in three of the six evaluation times, showing a proportionality between $\mathrm{K}^{+}$ concentrations and $\mathrm{K}_{2} \mathrm{O}$ rates applied. Similar results were found by Rossetto et al. (2004) in an experiment also in a Typic Hapludult (Argissolo Vermelho), showing that the application of $\mathrm{K}_{2} \mathrm{O}$ based fertilizers increased the $\mathrm{K}^{+}$concentration in the soil solution.

Higher $\mathrm{K}^{+}$concentrations were expected in the 0.4-0.6 m layer (Table 6) when compared to the other evaluated layers, which would characterize the leaching process, mainly when considering the rainfall events occurred. The highest $\mathrm{K}^{+}$ concentrations in the 0.4-0.6 m soil layer was found at 122 DAP (establishment stage), which corresponds to less than half of the sugarcane cycle; similar results were found for the other soil layers evaluated in the present study.

\section{CONCLUSIONS}

The $\mathrm{NO}_{3}^{-}$concentration in soils under sugarcane crops in the plant crop cycle is higher at the beginning of the crop cycle, whereas the $\mathrm{K}^{+}$ concentration is higher at the end of the crop cycle. The $\mathrm{NO}_{3}{ }^{-}$and $\mathrm{K}^{+}$concentrations in the soil solution are dependent on the evaluation time, soil layer, and $\mathrm{N}$ and $\mathrm{K}_{2} \mathrm{O}$ rates applied via fertigation.
The highest $\mathrm{NO}_{3}{ }^{-}$concentration $\left(264 \mathrm{mg} \mathrm{L}^{-1}\right)$ was found in the 0.0-0.2 soil layer at 236 days after planting (DAP), corresponding to the harvest time. The highest $\mathrm{K}^{+}$concentration (377 ppm) was found in the $0.0-0.2$ soil layer at $122 \mathrm{DAP}$, corresponding to the crop establishment stage. $\mathrm{No}_{\mathrm{NO}_{3}}^{-}$and $\mathrm{K}^{+}$ leaching to deep soil layers $(>0.4 \mathrm{~m})$ was found; similar concentrations were found for these ions in the three evaluated soil layers, denoting the good efficiency of fertilizer application via fertigation for sugarcane crops.

\section{REFERENCES}

ANDRADE JÚNIOR, A. S. et al. Demanda hídrica da cana-de-açúcar, por balanço de energia, na microrregião de Teresina, Piauí. Agrometeoros, v. 25 , n. 1, p. $217-226,2017$.

ANDRADE JÚNIOR, A. S. et al., Crescimento da cana-de-açúcar ( $1^{\mathrm{a}}$ soca) sob diferentes níveis de fertirrigação potássica. In: CONGRESSO NACIONAL DE IRRIGAÇÃO E DRENAGEM, XXI., 2011, Petrolina. Anais... Petrolina: ABID, 2011. p. CD-ROM.

ANDRADE, E. M. et al. Impacto da lixiviação de nitrato e cloreto no lençol freático sob condições de cultivo irrigado. Ciência Rural, v. 39, n. 1, p. 88-95, 2009. 
BASTOS, E. A.; ANDRADE JÚNIOR, A. S. Boletim agrometeorológico de 2013 para o município de Teresina, Piauí. Teresina: Embrapa Meio-Norte, 2014. 39 p. (Documentos, 228).

BRASIL. AGÊNCIA EMBRAPA DE INFORMAÇÃO TECNOLÓGICA - AGEITEC. Exigências climáticas da cana de açúcar. Disponível em: <http:// www.agencia.cnptia.embrapa.br/gestor/cana-deacucar/arvore/

CONTAG01_10_711200516716.html>. Acesso em: 23 fev. 2016

CAMARGO, L. et al., Sistema radicular da cana-deaçúcar cultivada sob diferentes sistemas de preparo de solo. IN: CONGRESSO BRASILEIRO DE ENGENHARIA AGRICOLA, XLVI., 2017, Maceió. Anais... Maceió: CONBEA, 2017. p. 1-5.

COELHO, E. F. et al. Concentração de nitrato no perfil do solo fertirrigado com diferentes concentrações de fontes nitrogenadas. Revista Brasileira de Engenharia Agrícola, v. 18, n. 3, p. 263-269, 2014.

DOORENBOS, J.; KASSAM, A. H. Tradução de GHEYI, H. R. et al. Efeito da água no rendimento das culturas. 2. ed. Campina Grande: UFPB, 2000. 221 p. (Estudos FAO: Irrigação e Drenagem, 33).

FLORES, R. A. et al. Potássio no desenvolvimento inicial da soqueira de cana crua. Pesquisa Agropecuária Brasileira, v. 42, n. 1, p. 106-111, 2012.

FRANCO, H. C. et al. Aproveitamento pela cana-deaçúcar da adubação nitrogenada de plantio. Revista Brasileira de Ciência do Solo, v. 32, sup., p. 2763 2770, 2008.

FRANCO, H. C. et al. Nitrogen in sugarcane derived from fertilizer under Brazilian field conditions. Field Crops Research, v. 121, n. 1, p. 29-41, 2011.

FREITAS , J. R. et al. Efeito da adubação potássica via solo e foliar sobre a produção e a qualidade da fibra em algodoeiro (gossypium hirsutum L.). Pesquisa Agropecuária Tropical, v. 37, n. 2, p 106112, 2007.

GAVA, G. J. C. et al. Utilização do nitrogênio da ureia $\left(15^{\mathrm{N}}\right)$ e da palhada $\left(15^{\mathrm{N}}\right)$ por soqueira de canade-açúcar cultivada em solo coberto com palhada. Pesquisa Agropecuária Brasileira, v. 6, n. 11, p. 1347-1354, 2001.

GIL, M. et al. Emitter discharge variability of subsurface drip irrigation in uniform soils: effect on water-application uniformity. Irrigation Science, v. 26, n. 1, p. 451-458, 2008.

JORIS, H. A. W. Nitrogênio na produção de canade-açúcar: aspectos agronômicos e ambientais. 2015. 134 f. Tese (Doutorado em Agricultura Tropical e Subtropical: área de concentração em Gestão de Recursos Agroambientais). Instituto Agronômico de Campinas, Campina, 2015.

MARIN, F. R. Zoneamento agrícola. Disponível em: < https://www.agencia.cnptia.embrapa.br/gestor/ cana-deacucar/arvore/

CONTAG01_64_22122006154840.html>. Acesso em: 26 ago. 2019.

MELO, F. B.; ANDRADE JÚNIOR, A. S.; PESSOA, B. L. O. Levantamento, zoneamento e mapeamento pedológico detalhado da área experimental da Embrapa Meio-Norte em Teresina, PI. Teresina: Embrapa Meio-Norte, 2014. 47 p. (Documentos, 231).

MENDES, W. C. et al. Lixiviação de nitrato em função de lâminas de irrigação em um solo argiloso e em um solo arenoso. Irriga, v. 1, n. 1, p. 47-56, 2015 .

MIELNICZUK, J. Avaliação da resposta das culturas ao potássio em ensaios de longa duração: experiências brasileiras. In: YAMADA, T.; MUZZILLI, O.; USHERWOOD, N. R. (Eds.). Potássio na agricultura brasileira. Piracicaba: Instituto da Potassa e Fosfato, 1982. p. 289-303.

OLIVEIRA, F. C. et al. Lixiviação de nitrato em um Latossolo Amarelo distrófico tratado com lodo de esgoto e cultivado com cana-de-açúcar. Sentia Agrícola, v. 58, n. 1, p. 171-180, 2001.

OLIVEIRA, E C. A. et al. Acúmulo e alocação de nutrientes em cana-de-açúcar. Revista Ciência Agronômica, v. 43, n. 3, p. 579-588, 2011.

OLIVEIRA, E C. A. et al. Extração e exportação de nutrientes por variedades de cana-de-açúcar cultivadas sob irrigação plena. Revista Brasileira de Ciência do Solo, v. 34, n. 4, p. 1343-1352, 2010.

PENATTI, C. P. Adubação da cana-de-açúcar - 30 anos de experiência. 1. ed. Itu, SP: Ottoni, 2013. $347 \mathrm{p}$.

RICHARDS, L. A. Diagnosis and improvement of saline and alkali soils. 1. ed. Washington, US: LWW, 1954. 160 p.

ROSOLEM, C. A. et al. Lixiviação de potássio da palha de espécies de cobertura de solo de acordo com a quantidade de chuva aplicada. Revista 
Brasileira de Ciência do Solo, v. 27, n. 2, p. 355362, 2003.

ROSSETTO, R. et al. Calagem para cana-de-açúcar e sua interação com doses de potássio. Bragantina, v. 63, n. 1, p. 105-119, 2004.

ROSSETTO, R. et al. Potássio na Cana-de-açúcar. 1. ed. Campinas, SP: Instituto Agronômico, 2008. 822 p.

SAS Instituto. SAS/STA® 14.1 Uses Glide. Carey, 2015. Disponível em: http://supporthttp:// support.sas.com/documentation/cdl/en/statug/68162/ PDF/default/statug.pdf $>$. Acesso em: 26 jan., 2016.

SANTOS, V. R. et al. Crescimento e produtividade agrícola de cana-de-açúcar em diferentes fontes de fósforo. Revista Brasileira de Engenharia Agrícola e Ambiental, v. 13, n. 4, p. 389-396, 2009.

SILVA, D. F. et al. Análise de Nitrato e Amônio em Solo e Água. 1. ed. Sete Lagoas, MG: Embrapa Milho e Sorgo, 2010. 56 p.

SILVA, F. C. et al. Manejo de $\mathrm{N}$ fertilizantes para a cana-de-açúcar com colheita crua, no contexto ecológico, por um modelo de simulação. In: ENVIRONMENTAL AND HEALTH WORLD CONGRESS, 2006, Santos. Anais... Santos: Embrapa Informática Agropecuária, 2006. p. 249253.

SILVA-OLAYA, A. M.; CERRI, C. P.; CERRI, C. Comparação de métodos de amostragem para avaliação do sistema radicular da cana-de-açúcar. Revista de Ciências Agrícolas, v. 34, n. 1, p. 7-16, 2017.

TRIVELIN, P. C. O.; VICTORIA, R. L.; RODRIGUES, J. C. S. Aproveitamento por soqueira de cana-de-açúcar de final de safra do nitrogênio da aquamônia- ${ }^{15} \mathrm{~N}$ e Ureia $-{ }^{15} \mathrm{~N}$ aplicado ao solo em complemento à vinhaça. Pesquisa Agropecuária Brasileira, v. 30, n. 12, p. 1375-1385, 1995.

VITTI, G. C. et al. Nutrição e adubação da canade-açúcar. 1. Ed. Bebedouro, SP: [s.n.], 2005. 78 p. 